\title{
Diarrhoea Patients in Sub-Saharan Africa with Low School Performance and Social Status: Relationship with Chronic Intestinal Parasitosis (Short communication)
}

D. Dorko (Dominik Dorko)', P. Juris (Peter Juris)', B. Durcova (Barbora Durcova)', C. Mulama (Catherine Mulama) 1, , M. Bartkoviak (Mario Bartkoviak) 1,2, V. Krcmery (Vladimír Krcmery)1,2, G. Mikolasova (Gertruda Mikolasova)', D. Kimuli (Daria Kimuli)', N. Jalili (Nasir Jalili) 1.2

1 Tropicteam St. Elizabeth University, Slovak Tropical Institute,

Bratislava and School of Medicine, Institute of Microbiology, Comenius University,

Bratislava, Slovakia Primary Grammar School Mazare Sharif, Rep of Afganistan

${ }^{2}$ SEU PhD. And MSc. Program, Nairobi, Kenya and Maternity Center Gordim, South Sudan

\section{E-mail address:}

tropicteam@gmail.com

\section{Reprint address:}

Nasir Jalili MD

Inst of Microbiology, School of Med, and PG School Mazare Sharif

Republic of Afganistan

Source: Clinical Social Work and Health Intervention

Pages: $20-22$
Volume: 9

Issue: 4

\section{Reviewers:}

Moses Kimon

MPC Nairobi, Kenya

Johnson Mawole

Cuea Mwanza, Rep of Tanzania

\section{Key words:}

Geohelminths, After-genocide Area of Social Instability.

\section{Publisher:}

International Society of Applied Preventive Medicine i-gap

CSWHI 2018; 9(4): 20 - 22; DOI 10.22359/cswhi_9_4_03 (c) 2018 Clinical Social Work and Health Intervention 


\section{Abstract:}

The occurrence of enteric parasites (geohelminths - GH) in developing countries is high. Studies on prevalence or incidence of GH are one of the possibilities to focus the attention of the health care politics to this particular problem. The aim of this study was to assess the prevalence of GH in a rural areas of Rwanda, Burundi, and South Sudan, all countries after huge social changes, eg. civil war or genocide within last 30 years. Low school performance is a result of chronic anemia related to $\mathrm{GH}$.

\section{Introduction}

The occurrence of enteric parasites (geohelminths - GH) in developing countries is high. Studies on prevalence or incidence of $\mathrm{GH}$ are one of the possibilities to focus attention of health care politics to this particular problem. The aim of this study was to assess the prevalence of $\mathrm{GH}$ in a rural areas of Rwanda, Burundi, and South Sudan, all countries after huge social changes, such as civil war or genocide within the last 30 years. (1) Low school performance is a result of chronic anemia related to $\mathrm{GH}$.

\section{Patients and Methods}

Monthly reports on GM incidence in three rural hospitals (Outpatient Departments) in clinics in Rwanda (Bigugu), Burundi (Gasura), and Mapuordit (South Sudan) have been analyzed from March $1^{\text {st }}$ 2017 till Feb 2018 in patients with signs and symptoms of intestinal infection. Stool samples taken in plastic caps were examined by microscopy after adding $\mathrm{KOH}+\mathrm{H}_{2} \mathrm{O}$ saline (Kato-Katz Method) and centrifuged within 30 minutes (native microscopy) with a trained medical technician.

\section{Results and Discussion}

Analysis of 884 stool samples was performed with $37 \%$ of these were positive. The commonest pathogens were Entamoeba histolytica (47.3\%), Ascaris lumbricoides (17.22\%), and Giardia intestinalis (11.83\%). Slight environmental differences between three Sub-Saharan African countries have been observed, however, they were insignificant, e.g. $54 \%$ of positive samples were in females (who are predominantly preparing food), as well as in those older than 16 years of age (adults), also not significant $(\mathrm{p}>0,05)$ probably due to deworming programs in children. Intestinal parasitosis due to consumption of folic acid, iron, and B12 vitamin are responsible for so-called "consumption" anemia, responsible for worse school performance in countries with poor access to clean water due to socially/ economically instable environments after conflicts (genocide 1982 - 2010) or famine, with destruction of hygienic infrastructure and water supplies $(1,2)$.

\section{Conclusion}

Intestinal parasites are a major cause of anemia in developing countries worldwide, mainly in Sub-Saharan Africa and South-east Asia. Anemia is directly responsible for low school performance of children/adolescents/ mothers, where apart of parasitosis of the gut $(\mathrm{GH})$ malaria and post-partum bleeding contributes to anemia, many times powered by malnutrition or religion-related diet with less iron, B12 vitamin, folic acid, D vitamin, cobalt, and other key elements for hematopoiesis. Therefore, large campaigns against soil-transmitted helminths (STH or GH) and deworming programs with twice a year albendazole (+praziquantel) are supported 
by philanthrops, such as Melinda and Bill Gates, World Bank (to combat malaria, HIV, $\mathrm{TB}$, and diarrhea). However, investments to environmental health and clean water supply, within 2030 Sustainable Development Goals agenda are crucial as social work and health intervention.

\section{References}

1. MOLNAROVA K et al (2017) Low Number of Neuroinfections in Migrants to Greece from Syria and Iraq Comparison to Migrants from Burundi and Congo to Rwanda. Clinical Social Work and Health Intervention Vol. 8 No. 22017

2. BALUCHOVA B, MAMOVA A (2017) The role of implementation and communication of MANTRA Water, sanitation and hygiene program in improving public health in Odisha state (India) Neuroendocrinology Letters 2017; 38(Suppl.1):35-39 